\title{
Cancer screening for older people: to screen or not to screen
}

\author{
Claudia KY Lai *, Ayumi Igarashi, Natalie MY Lau, Clare TK Yu
}

This article was published on 1 Sep 2017 at www.hkmj.org.

\section{A B S T R A C T}

In this scoping review, the evidence of the benefits of screening older people for the five most common types of cancer in Hong Kong, namely colorectal, lung, breast, liver, and prostate cancers, is discussed. Although cancer treatments can be extensive and a good prognosis is less likely if cancer is diagnosed at a late stage, screening programmes for older people in primary care remain a matter of contention. The general recommendation for the screening of older people is to adopt an individualised approach that takes account of not only age but also co-morbidity, life expectancy, harms and benefits, and patient's preference.
Hong Kong Med J 2017;23:503-16

DOI: $10.12809 / \mathrm{hkmj} 166154$

${ }^{1} \mathrm{CKY}$ Lai ${ }^{*}, \mathrm{PhD}, \mathrm{RN}$

${ }^{2} \mathrm{~A}$ Igarashi, PhD, RN

${ }^{1}$ NMY Lau, MN, BA

${ }^{1} \mathrm{CTK} Y u$, BSc

School of Nursing, The Hong Kong Polytechnic University, Hunghom, Hong Kong

2 School of Health Sciences and Nursing, Graduate School of Medicine, The University of Tokyo, Tokyo, Japan

* Corresponding author: claudia.lai@polyu.edu.hk

\section{Introduction}

Cancer, a word that evokes fear in most people, is the second leading cause of death worldwide; 8.8 million of deaths due to cancer are estimated to have occurred in $2015 .{ }^{1}$ Globally, the most common types of cancer are lung, breast, bowel, and prostate. In Hong Kong, the five leading types of cancer (combining both males and females) are, in order of incidence, colorectal, lung, breast, liver, and prostate cancers. ${ }^{3}$ Because the incidence of cancer increases with age, early detection can help reduce the burden of treatment and is more likely to lead to a better outcome if the cancer is adequately treated. Although there are guidelines on the recommended ages at which to begin screening for different types of cancer, there is less guidance on the screening needs of older adults. ${ }^{4}$

\section{Controversies over cancer screening for older people}

Cancer screening for early detection is promoted globally because of the link between an ageing population and an increase in the prevalence of cancer worldwide, on the supposition that this will improve the prognosis of cancer patients and may therefore be beneficial for older people. ${ }^{5}$ Of note, 33 countries have joined the International Cancer Screening Network and are participating in active population-based screening programmes for breast, colorectal, cervical, and lung cancers. ${ }^{6}$ There are practice guidelines recommending the ages at which to start screening for various types of cancer, but there is less information about when to cease screening, specifically in older people. Epidemiological studies of cancer in people aged 70 years or older are rarely reported in the literature; even if there are such studies, only subgroup analyses are found. ${ }^{7}$ The efficacy of screening older people for cancer remains controversial. Even though cancer rates have increased with age, this does not imply that routine cancer screening is recommended or even appropriate for older people. ${ }^{8}$

The aims of this review were to examine the evidence regarding screening for cancer in older people and to present an overview of the current state of knowledge about controversies and recommendations with regard to screening for the top five most common kinds of cancer in older people in Hong Kong.

\section{Methods}

A scoping review was conducted to explicate current discussions of recommendations for screening older adults for cancer. A scoping review was deemed to be appropriate because it is often used to address broad topics, the literature on which may include studies with numerous designs. The approach described by Arksey and O'Malley was adopted. ${ }^{9}$

The databases of MEDLINE, EMBASE, the Web of Science, the Cochrane Library, CINAHL, and SCOPUS were searched using the following strategies:

- Strategy $1-\left(\right.$ Elder* $\left.^{*}\right)$ and (Cancer screening or cancer prevention) and (Mortality or morbidity)

- Strategy 2-(Elder*) and (Cancer screening or cancer prevention) and (Effect or efficacy or effective*) 


\section{針對老年人的癌症篩查：是否應作普查？}

賴錦玉、五十嵐步、劉明欣、余子趟

本文獻綜述討論有關癌症篩查為老年人帶來好處的證據, 包括以下最 常見的五大癌症：結腸直腸癌、肺癌、乳腺癌、肝癌和前列腺癌。縱 使癌症治療方法十分廣泛, 而且晚期癌症預後較差, 但在基層醫療層 面為老年人作癌症篩查仍具爭議性。一般針對老年人癌症篩查的建議 是採取個人化的方法, 即不僅考慮患者的年齡, 還要關注其共病、預 期壽命、對患者的利弊, 以及個人選擇。
Searches were conducted for studies in which the population was restricted to those aged 65 years or above. The search fields included abstracts and titles, studies written in English, and studies published in the last 10 years only (January 2007 to April 2017). We included only studies that evaluated screening for five types of cancer (colorectal, lung, breast, liver, and prostate). Studies that employed retrospective data analysis, simulation modelling, and observational, experimental (randomised controlled trials [RCTs]) or uncontrolled clinical trials were included. Systematic reviews were also included, but discussion papers that did not describe the process by which the database searches were conducted were excluded. Articles that discussed knowledge or attitudes to cancer screening and surveillance monitoring were also excluded.

Three members of the team screened all of the titles of the papers that were retrieved; papers that were considered irrelevant were discarded. Next, irrelevant papers were also excluded after the abstract and/or the full paper had been reviewed. At least two members independently read the full text of all of the papers that were potentially relevant and selected those that met the criteria for inclusion. The final selection of papers was achieved through a series of virtual online discussions that continued until a consensus was reached.

Other reports relevant to the topic found or cited in text in the reviewed papers were also included. As a result, 13 papers were added to the 23 papers from the scoping search. A total of 36 papers were included for review, with $13,3,14,1$, and 10 papers that concerned the screening of colorectal, lung, breast, liver, and prostate cancers, respectively (Fig). Three of the papers examined the evidence of

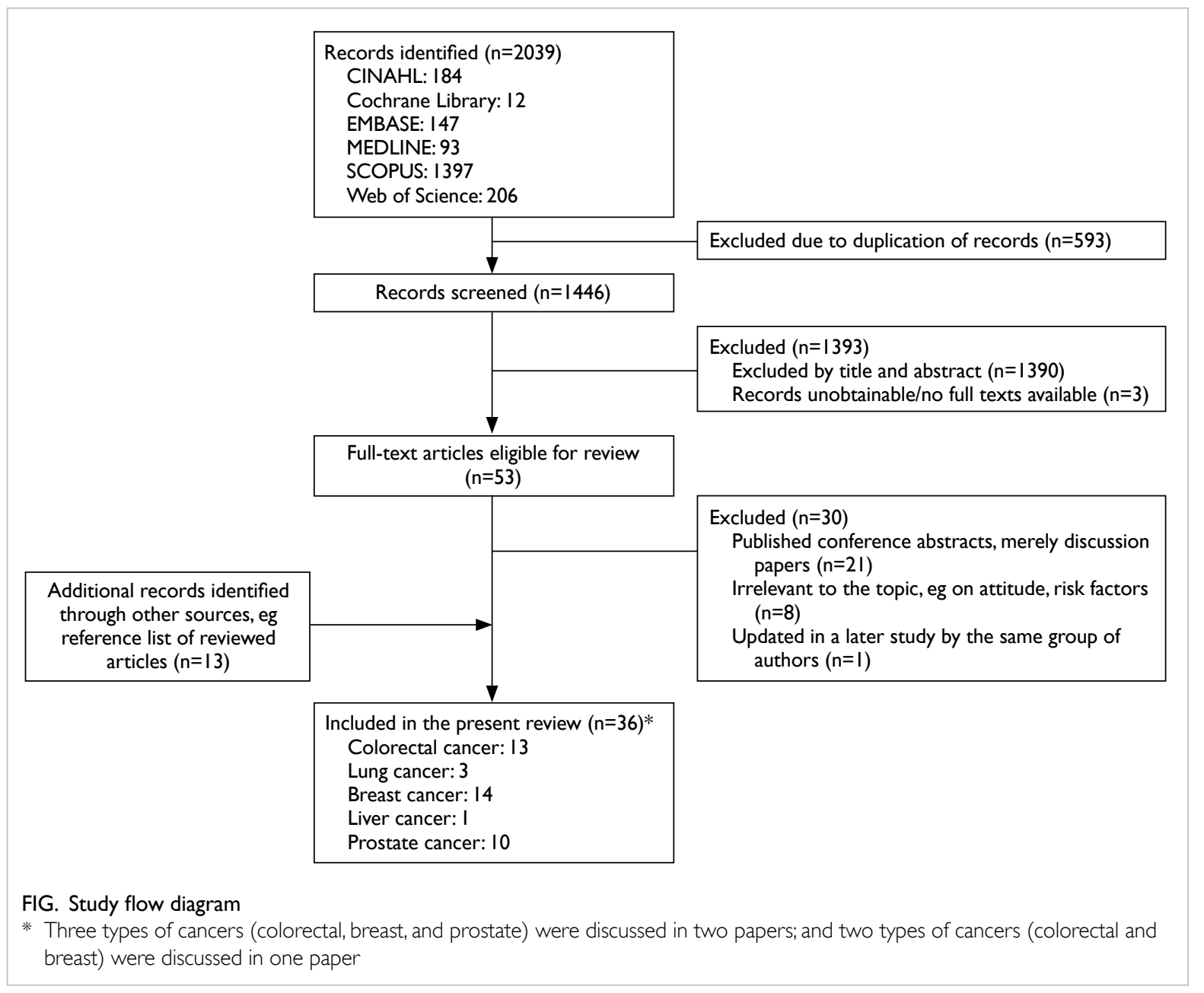


more than one type of cancer and have therefore been included in different sections for review purposes. Recommendations for screening guidelines from national institutes or professional associations have also been included in each section after discussion of the reviewed papers. In the papers being reviewed, 'benefit' in screening is defined as early detection, survival, or reduced risk in mortality or comorbidity; 'harm' is defined as mortality (death due to the specific type of cancer under investigation), false-positive and false-negative test results, or overdiagnosis.

\section{Colorectal cancer screening}

The faecal occult blood test (FOBT), barium enema, sigmoidoscopy, and colonoscopy are used to screen for colorectal cancer. ${ }^{4,10}$ Quarini and Gosney ${ }^{11}$ reviewed all available articles on colorectal cancer screening in MEDLINE from 1990 to 2007. They found limited evidence relating to the screening of older people. ${ }^{11}$

In a recent population-based simulation study, Meester et $\mathrm{al}^{12}$ analysed the number of deaths from colorectal cancer that were attributable to non-screening in the US; most such deaths were attributable to non-screening. Similar findings have been reported in Germany where screening colonoscopy has been offered since 2002. Brenner et al $^{13,14}$ used simulation modelling based on Germany's national data and found that screening colonoscopies have great potential in the prevention and early detection of colorectal cancer, with a low risk of over-diagnosis. Moreover, the majority of prevented cases would have occurred at the age of 75 years or older. ${ }^{14}$ Rozen et $\mathrm{al}^{15}$ also reported that those aged 75 years or older, rather than younger individuals, could benefit from screening.

Using colorectal cancer-specific mortality data between 1991 and 2001 obtained from the National Center for Health Statistics database in the US, Maheshwari et $\mathrm{al}^{16}$ compared the impact of prematurely stopping screening with the maximal potential benefit expected from lifelong screening. A total of $80 \%$ of the maximal benefit from screening was achieved by screening up to the age of 82 years. Kahi et $\mathrm{al}^{17}$ examined the survival of older people after colonoscopy using a retrospective cohort analysis of those aged 75 years or above and followed up for a median of 5.95 years. The authors reported that colonoscopy was safe and yielded clinically significant findings in $15 \%$ of older patients. ${ }^{17}$

van Hees et $\mathrm{al}^{18}$ used a simulation model to determine up to what age colorectal cancer screening should be considered in unscreened older people with no, moderate, or severe co-morbidity. They concluded that if the physical condition of unscreened older people with different co-morbidity status permits them to undergo a colonoscopy, screening should be considered up to the ages of 86,83 , and 80 years for no, moderate, and severe co-morbidity, respectively. van Hees' team also reported that fewer co-morbidities were associated with screening at older ages. ${ }^{19}$ Lansdorp-Vogelaar et $\mathrm{al}^{20}$ and Gross et $\mathrm{al}^{21}$ whose studies are included in this review, also arrived at a similar conclusion.

Not all studies found positive results for colorectal screening. A longitudinal study by Fillenbaum et $\mathrm{al}^{22}$ observed no significant association between cancer screening and population-level health-related outcomes (including mortality).

Over-diagnosis and complications from treatment are often concerns in the promotion of screening. Although colorectal polyps are detected more frequently in older people, especially those over the age of 80 years, the view is that to conduct a colonoscopy in older people is to introduce a higher risk for only a smaller gain in life expectancy (15\%) than would be the case with younger people. ${ }^{23}$ Cancer screening in people older than 75 years remains controversial because they have not been included in RCTs on the efficacy of screening studies. ${ }^{10}$

The guidelines from the National Cancer Institute, ${ }^{24}$ the American Cancer Society, ${ }^{25}$ and the US Preventive Services Task Force (USPSTF) ${ }^{26}$ generally recommend that people who are at an average risk of developing colorectal cancer or who have a family history of colorectal cancer or colorectal polyps begin regular screening for colorectal cancer at the age of 50 years. Specifically, the USPSTF recommends against screening with colonoscopy beyond the age of 85 years. ${ }^{27}$ The Canadian Task Force on Preventive Health Care recommends against screening with colonoscopy at all ages, but it does support the use of FOBT or faecal immunochemical testing for screening every alternate year and with sigmoidoscopy every 10 years for those aged 50 to 74 years. ${ }^{27}$

In Hong Kong, the Department of Health launched a 3-year Colorectal Cancer Screening Pilot Programme in 2016 to provide subsidised screening for those born between 1946 and 1948. The Hong Kong Anti-Cancer Society recommends that individuals aged 50 to 75 years with an average risk of developing colorectal cancer should consider undergoing an annual FOBT and flexible sigmoidoscopy every 5 years or a colonoscopy every 10 years. ${ }^{28}$ Overall, the current literature suggests that colorectal cancer screening is beneficial, but that age as well as morbidity and life expectancy should be considered when determining the age at which screening should stop. Screening colonoscopy in very elderly patients (aged $\geq 80$ years) should be performed only after carefully considering the potential benefits and risks, and the preferences of the patient. A summary of the literature review of screening for colorectal cancer is shown in Table $1 .{ }^{11-22,27}$ 
TABLE I. Screening for colorectal cancer: summary of literature review ${ }^{11-22,27}$

\begin{tabular}{|c|c|c|c|c|}
\hline Study & Country & Study design & Objective(s) & Sample \\
\hline $\begin{array}{l}\text { Fillenbaum et } \\
\text { al, }^{22} 2007\end{array}$ & US & $\begin{array}{l}\text { Longitudinal cohort } \\
\text { study (followed up } \\
\text { for } 4-6 \text { years) }\end{array}$ & $\begin{array}{l}\text { To determine the effect } \\
\text { of health behaviours } \\
\text { such as cancer } \\
\text { screening on population } \\
\text { health-related outcomes }\end{array}$ & $\begin{array}{l}\text { A representative } \\
\text { community sample of } \\
\text { those aged } \geq 71 \text { years } \\
\text { ( } n=2230 \text { ) from the Duke } \\
\text { Established Populations } \\
\text { for Epidemiologic } \\
\text { Studies of the Elderly }\end{array}$ \\
\hline $\begin{array}{l}\text { Kahi et al. }{ }^{17} \\
2007\end{array}$ & US & $\begin{array}{l}\text { Retrospective } \\
\text { cohort study }\end{array}$ & $\begin{array}{l}\text { To describe the } \\
\text { findings, survival rate, } \\
\text { and predictors of } \\
\text { mortality of older people } \\
\text { post-colonoscopy }\end{array}$ & $\begin{array}{l}\text { Older individuals aged } \\
\geq 75 \text { years }(n=404) ; \text { in } \\
\text { two hospitals during } \\
1999-2000\end{array}$ \\
\hline
\end{tabular}

\begin{tabular}{|c|c|c|c|}
\hline $\begin{array}{l}\text { Maheshwari et } \\
\text { al, }^{16} 2008\end{array}$ & US & $\begin{array}{l}\text { Life-table analysis } \\
\text { of the risks of dying } \\
\text { from colorectal } \\
\text { cancer or from all } \\
\text { causes }\end{array}$ & $\begin{array}{l}\text { To examine the impact } \\
\text { of age on the benefits } \\
\text { of colorectal cancer } \\
\text { screening }\end{array}$ \\
\hline $\begin{array}{l}\text { Quarini and } \\
\text { Gosney, }{ }^{11} \\
2009\end{array}$ & $\begin{array}{l}\text { UK (first } \\
\text { author) }\end{array}$ & $\begin{array}{l}\text { A methodical } \\
\text { approach to } \\
\text { searching the } \\
\text { literature (1990- } \\
\text { 2007) }\end{array}$ & $\begin{array}{l}\text { To review the current } \\
\text { literature on colorectal } \\
\text { cancer screening }\end{array}$ \\
\hline $\begin{array}{l}\text { Gross et al, }{ }^{21} \\
2011\end{array}$ & US & $\begin{array}{l}\text { Retrospective study } \\
\text { using Medicare } \\
\text { claims data (1993- } \\
\text { 2002) }\end{array}$ & $\begin{array}{l}\text { To identify the harms } \\
\text { and benefits of } \\
\text { screening colonoscopy } \\
\text { based on sex, age, and } \\
\text { co-morbidity in different } \\
\text { older groups }\end{array}$ \\
\hline $\begin{array}{l}\text { Rozen et al, }{ }^{15} \\
2011\end{array}$ & Israel & $\begin{array}{l}\text { Retrospective study } \\
\text { using Israel National } \\
\text { Cancer Registry } \\
\text { data (1980-2008) }\end{array}$ & $\begin{array}{l}\text { To describe the } \\
\text { long-term results of } \\
\text { colonoscopies and } \\
\text { I-FOBTs in those aged } \\
\geq 75 \text { years }\end{array}$ \\
\hline
\end{tabular}

LansdorpUS al, ${ }^{20} 2014$

\section{Collaborative} modelling using 7 well-established cancer simulation models $\begin{array}{ll}\text { Brenner et al, }{ }^{13} \text { Germany } & \begin{array}{l}\text { Simulation } \\ \text { modelling }\end{array}\end{array}$

Brenner et al, ${ }^{13}$ Germany
2015 $\begin{aligned} & \text { Simulation } \\ & \text { modelling }\end{aligned}$

Brenner et al, ${ }^{14}$ Germany
2015

\section{Simulation} modelling (note: same study as Brenner et $\mathrm{al}^{13}$ but with another question studied)

\section{To investigate the} harms and benefits of cancer screening by age and co-morbidity to inform screening cessation (including mammograms, I-FOBTs, and prostatespecific antigen tests)

To estimate the longterm impact of the country's screening colonoscopy offered to all individuals of age $\geq 55$ years since 2002

To quantify the effect of screening colonoscopy on prevention, early detection, and overdiagnosis in the last 10 years

\section{Data from the}

Surveillance,

Epidemiology, and End

Results programme and the National Center for Health Statistics databases (1991-2001)

Not applicable

Individuals of 67-94 years old diagnosed with primary colorectal cancer, compared with a subset of 50000 matched non-cancer cases

Among the patients $(n=271)$, only 6 diagnosed as having colorectal cancer

Cohorts aged 66-90 years in 2010 with no, mild, moderate, or severe co-morbidity; each cohort was compared with an average-health cohort

A total of 4408571 first-time screening colonoscopy for the period 2003-2012 (data from the German national screening colonoscopy registry)

(As above)

\section{Key findings / conclusion}

No significant association between cancer screening and population-level health-related outcomes (as measured by functional status, self-rated health, hospitalisations, and mortality rate); disease-specific screens were useful at a personal level but not associated with population-level health

The median survival of those aged 75-79 years was $>5$ years if their Charlson score was $\leq 4$; among those aged $\geq 80$ years, the median survival was $<5$ years regardless of Charlson score; age and morbidity were predictors of death

Approximately $80 \%$ of the maximum benefit from screening was achieved by screening until age 82 years

Very little research on colorectal cancer specifically in elderly people; present screening programmes did not reflect the heath needs of older people

The positive effect of screening for colorectal cancer was the same for both sexes; screening decisions should not be based solely on age

Approximately $41 \%$ of colorectal cancers occurred in those aged $\geq 75$ years, who were diagnosed clinically and not by screening; a one-time set of I-FOBTs identified nearly all colorectal cancers in older and in younger patients

Older people with no, mild, moderate, and severe co-morbidities could benefit from screening until the ages of 76-78, 74, 72, and 66 years, respectively, and still experienced similar levels of harm and benefit as individuals of average health up to age 74 years; estimates of harms and benefits by co-morbidity could help doctors and patients to decide on when to cease screening

Number of prevented colorectal cancer cases projected to increase from $<100$ in 2005 to approximately 6500 cases in 2015 ; the screening programme would lead to significant reductions in the burden of care despite modest participation rates

Colonoscopies had the advantages of prevention and early detection, with a low risk of over-diagnosis; 180000 colorectal cancers are estimated to have been prevented $(97 \%$ were prevented by screening colonoscopies done up to age 75 years); $1 / 121$ screening colonoscopies were early detected up to age 80 years $(89 \%$ by screening colonoscopies up to age 75 years); over-diagnosed in 1/1089 screening colonoscopies (58\% arose from screening colonoscopies done on those age $>70$ years) 
TABLE I. (cont'd)

\begin{tabular}{|c|c|c|c|c|c|}
\hline Study & Country & Study design & Objective(s) & Sample & Key findings / conclusion \\
\hline $\begin{array}{l}\text { van Hees et } \\
\text { al, }^{18} 2014\end{array}$ & US & $\begin{array}{l}\text { Microsimulation } \\
\text { modelling }\end{array}$ & $\begin{array}{l}\text { To examine up to } \\
\text { what age colorectal } \\
\text { screening should be } \\
\text { conducted among the } \\
\text { unscreened elderly } \\
\text { with no, moderate, and } \\
\text { severe co-morbidity }\end{array}$ & $\begin{array}{l}\text { A total of } 45 \text { cohorts } \\
\text { simulated for each } \\
\text { age between } 76 \text { and } \\
90 \text { years with no, } \\
\text { moderate, and severe } \\
\text { co-morbidity; each } \\
\text { cohort comprised } 10 \\
\text { million cases }\end{array}$ & $\begin{array}{l}\text { Colorectal screening needed to be } \\
\text { considered up to the ages of } 86,83 \text {, and } 80 \text {, } \\
\text { for those with no, moderate, and severe co- } \\
\text { morbidity, respectively }\end{array}$ \\
\hline $\begin{array}{l}\text { van Hees et } \\
\text { al, }^{19} 2015\end{array}$ & US & $\begin{array}{l}\text { (As above; note: } \\
\text { same study as van } \\
\text { Hees et al, }{ }^{18} 2014 \text { ) }\end{array}$ & $\begin{array}{l}\text { To identify the } \\
\text { determinants of benefits } \\
\text { for older people of } \\
\text { colorectal cancer } \\
\text { screening; to examine } \\
\text { the maximum age for } \\
\text { screening to remain } \\
\text { cost-effective }\end{array}$ & $\begin{array}{l}\text { A total of } 19200 \\
\text { cohorts simulated } \\
\text { based on age, gender, } \\
\text { race, screening history, } \\
\text { background risks, and } \\
\text { co-morbidity status; } \\
\text { each cohort consisted } \\
\text { of } 10 \text { million individuals }\end{array}$ & $\begin{array}{l}\text { Screening colorectal cancer based on age } \\
\text { was inefficient; individual factors should be } \\
\text { considered }\end{array}$ \\
\hline $\begin{array}{l}\text { Meester et al, }{ }^{12} \\
2015\end{array}$ & US & $\begin{array}{l}\text { Microsimulation } \\
\text { modelling analysis } \\
\text { designed for the } \\
\text { period } 1980-2030\end{array}$ & $\begin{array}{l}\text { To estimate the number } \\
\text { of colorectal cancer } \\
\text { deaths attributable to } \\
\text { non-screening }\end{array}$ & $\begin{array}{l}\text { A virtual population } \\
\text { created based on US } \\
\text { census data (similar } \\
\text { to the population in } \\
\text { life expectancy, and in } \\
\text { the natural history and } \\
\text { occurrence of colorectal } \\
\text { cancer) }\end{array}$ & $\begin{array}{l}\text { More than half of current US colorectal } \\
\text { deaths could be attributed to not screening; } \\
\text { increasing screening uptake in the population } \\
\text { was beneficial }\end{array}$ \\
\hline $\begin{array}{l}\text { Tazkarji et al, }{ }^{27} \\
2016\end{array}$ & $\begin{array}{l}\text { Canada } \\
\text { (first } \\
\text { author) }\end{array}$ & $\begin{array}{l}\text { A methodical } \\
\text { approach to search } \\
\text { the literature (2006- } \\
\text { July 2016) }\end{array}$ & $\begin{array}{l}\text { To guide family doctors } \\
\text { in devising screening } \\
\text { and treatment plans for } \\
\text { older patients }\end{array}$ & Not applicable & $\begin{array}{l}\text { Needed to consider age, life expectancy, } \\
\text { co-morbidities, functional status, risk and } \\
\text { benefits, and patient preferences when } \\
\text { recommending preventive health measures } \\
\text { to patients }\end{array}$ \\
\hline
\end{tabular}

\section{Lung cancer screening}

Chest X-rays, sputum cytology, and low-dose computed tomography (CT) have been used to screen for lung cancer. ${ }^{29}$ Although chest X-rays or sputum cytology have been used to check for signs of lung cancer, there is less evidence from RCTs to show that using them can lead to a reduction in the number of associated deaths. ${ }^{29}$ There is, however, some evidence from large-scale RCTs that low-dose $\mathrm{CT}$ screening can reduce lung cancer deaths. ${ }^{30}$

Oken et $\mathrm{al}^{31}$ compared annual chest radiographic screening with the usual care in the Prostrate, Lung, Colorectal, and Ovarian (PLCO) cancer screening trial. The participants were aged 55 to 74 years and were heavy smokers. Radiographic screening did not reduce lung cancer mortality when compared with the usual care. Aberle et al's National Lung Screening Trial ${ }^{32}$ in the US examined the effects of lung cancer screening by low-dose CT for participants aged 55 to 74 years who were either current or former (within the past 15 years) heavy smokers (at least 30 packs of cigarettes/year). An annual low-dose CT for 3 years reduced 20\% of deaths from lung cancer when compared with chest radiography.

Using simulation modelling, McMahon et $\mathrm{al}^{33}$ examined the potential benefits (life years saved or lung cancer deaths avoided) of 576 lung cancer screening programmes that included a variety of screening criteria in terms of age, smoking history, and the number and frequency of CT screenings. They concluded that it would be more efficient (measured in terms of the number of cancer deaths compared with no screening) if screening were extended to the age of 80 or 85 years. The potential harm of low-dose CT, however, should also be noted, such as false-positive and false-negative results, overdiagnosis, exposure to radiation, and an emotional toll on the individual concerned.

Based on the National Lung Screening Trial, ${ }^{32} \mathrm{a}$ systematic evidence review ${ }^{30}$ and modelling studies, the USPSTF has updated their guidelines. They now recommend that people aged 55 to 80 years who currently smoke or who have quit smoking within the past 15 years should undergo annual screening with low-dose CT. ${ }^{34}$ The USPSTF also recommends that screening be discontinued for those who have quit smoking for 15 years or who have developed a health problem that substantially limits their life expectancy or their ability or willingness to undergo curative lung surgery. ${ }^{30}$ The Hong Kong Anti-Cancer Society does not recommend any routine screening for the general population. Considering both life expectancy and co-morbidity status would help physicians to decide the necessity of screening in different individuals..$^{35} \mathrm{~A}$ summary of the literature 
review of screening for lung cancer is shown in Table $2 .^{31-33}$

\section{Breast cancer screening}

Clinical breast examinations and breast selfexaminations, mammograms, ultrasound, and magnetic resonance imaging, are all measures to screen for breast cancer, with the mammogram being the most widely used test.

A systematic review by Galit et $\mathrm{al}^{36}$ suggested that with a reasonable life expectancy and without severe co-morbidities, women aged 75 years or above are likely to benefit from mammography. Mo et $\mathrm{al}^{37}$ found that mammography screening alone for Chinese women over the age of 70 years with positive clinical breast examination results would save on the cost of ultrasonography without any loss in the effectiveness of screening. When co-morbidity and screening are considered, Lansdorp-Vogelaar et $\mathrm{al}^{20}$ showed that the benefits of a biennial mammography existed until the median ages of 76, 74, 72, and 66 years for older women with no, mild, moderate, or severe co-morbidity, respectively.

The EUROSCREEN Working Group reviewed observational studies and reported that the reduction of the breast cancer mortality rate was $38 \%$ to $48 \%$ for women who had actually been screened, with the rate of over-diagnosis of only $6.5 \%{ }^{38,39}$ They argued that the current controversy is related to the use of inappropriate methods that are incapable of revealing the true effect of screening, and that population-based mammography screening is of greater benefit than harm.

Using simulation modelling, Tejada et $\mathrm{al}^{40}$ evaluated seven screening policies to determine which combination of upper age limit and screening interval could maximise screening benefits for older women. Annual screening with an upper age limit of 80 years was found to be most effective in increasing the survival rate. ${ }^{40}$ Similarly, Sanderson et $\mathrm{al}^{41}$ found a significant reduction in the breast cancer mortality rate of older women who underwent an annual mammography compared with those who underwent a biennial or irregular mammography.

Some researchers have nonetheless taken a contrary view. Fillenbaum et $\mathrm{al}^{22}$ found no significant association between breast cancer screening and health-related outcomes such as self-rated health and mortality. Similarly, the benefits of screening were found to be limited due to a huge number of cases of over-diagnosis in the older population. ${ }^{5}$ Mandelblatt et $\mathrm{al}^{42}$ evaluated the effectiveness of 20 different mammography screening programmes using six established models of cancer incidence and mortality trends in the US. They reported that

TABLE 2. Screening for lung cancer: summary of literature review ${ }^{31-33}$

\begin{tabular}{|c|c|c|c|c|c|}
\hline Study & Country & Study design & Objective & Sample & Key findings / conclusion \\
\hline $\begin{array}{l}\text { Aberle et al, }{ }^{32} \\
2011\end{array}$ & US & $\begin{array}{l}\text { Randomised } \\
\text { controlled trial }\end{array}$ & $\begin{array}{l}\text { This NLST aimed to } \\
\text { determine whether annual } \\
\text { screening with low-dose } \\
\text { CT for } 3 \text { years could reduce } \\
\text { mortality from lung cancer }\end{array}$ & $\begin{array}{l}\text { Participants from } \\
33 \text { medical centres } \\
\text { ( } n=53456) ; \text { aged } 55-74 \\
\text { years with a history of } \\
\text { heavy smoking ( } 30 \\
\text { packs/year or had quit } \\
\text { within } 15 \text { years); low-dose } \\
\text { CT group ( } n=26722 \text { ) and } \\
\text { chest radiography group } \\
\text { ( } n=26732 \text { ) followed up } \\
\text { until } 2009\end{array}$ & $\begin{array}{l}\text { A } 20 \% \text { decrease in mortality from lung } \\
\text { cancer found in the low-dose CT group } \\
\text { when compared with the radiography group; } \\
\text { annual screening with low-dose CT for } 3 \\
\text { years reduced mortality from lung cancer } \\
\text { in the sample; there was also a high rate } \\
\text { of false-positive results in the low-dose CT } \\
\text { group }\end{array}$ \\
\hline $\begin{array}{l}\text { Oken et al, }{ }^{31} \\
2011\end{array}$ & US & $\begin{array}{l}\text { Randomised } \\
\text { controlled trial }\end{array}$ & $\begin{array}{l}\text { Radiographs were used in } \\
\text { a PLCO cancer screening } \\
\text { trial to determine the } \\
\text { outcome (mortality) of annual } \\
\text { screening (1993-2001) for } \\
\text { lung cancer of those who } \\
\text { currently smoke } 30 \\
\text { packs/year or who had quit } \\
\text { within } 15 \text { years }\end{array}$ & $\begin{array}{l}\text { Participants aged 55- } \\
74 \text { years ( } n=154901) \\
\text { followed up until 2009; } \\
\text { annual screening group } \\
\text { ( } n=77445 \text { ) and usual } \\
\text { care group ( } n=77456 \text { ); } \\
\text { data from a subset of } \\
\text { participants for the NLST } \\
\text { were also analysed }\end{array}$ & $\begin{array}{l}\text { Annual screening with chest radiographs } \\
\text { over a 4-year period did not significantly } \\
\text { decrease lung cancer mortality compared } \\
\text { with usual care, neither in the PLCO as a } \\
\text { whole nor in the subset of participants who } \\
\text { would have been eligible to enrol in the } \\
\text { NLST }\end{array}$ \\
\hline $\begin{array}{l}\text { McMahon et } \\
\text { al, }{ }^{33} 2014\end{array}$ & US & $\begin{array}{l}\text { Microsimulation } \\
\text { modelling }\end{array}$ & $\begin{array}{l}\text { To examine the potential } \\
\text { benefits (life years saved } \\
\text { or lung cancer deaths } \\
\text { avoided) of } 576 \text { lung cancer } \\
\text { screening programmes } \\
\text { that had variable screening } \\
\text { criteria (age, smoking history, } \\
\text { number and frequency of CT } \\
\text { screenings) }\end{array}$ & $\begin{array}{l}\text { Models adopted the } \\
\text { natural history parameters } \\
\text { of lung cancer calibrated } \\
\text { to the NLST to simulate } \\
\text { the life histories of US } \\
\text { men and women born in } \\
1950\end{array}$ & $\begin{array}{l}\text { Annual screening based on age and } \\
\text { smoking history in the NLST was inefficient; } \\
\text { screening up to ages } 80 \text { or } 85 \text { years would } \\
\text { be more efficient }\end{array}$ \\
\hline
\end{tabular}

Abbreviations: CT = computed tomography; NLST = National Lung Screening Trial; PLCO = Prostate, Lung, Colorectal, and Ovarian 
if the age of cessation was set at after 69 years, the reduction in mortality would be slight.

A Cochrane review examined the effect of mammography screening in terms of mortality and morbidity in a total sample of 600000 women. ${ }^{43}$ Screening led to a $15 \%$ reduction in mortality but the over-diagnosis and over-treatment rate was $30 \%$. The authors suggested that screening might not be doing more good than harm..$^{43}$ Of note, only one trial in this Cochrane review included women up to the age of 69 years. In their retrospective cohort study, Parvinen et a $\mathrm{l}^{44}$ found that a mammography screening programme for women up to the age of 74 years effectively reduced mortality rates in the older population, but that the reduction in rate was only $20 \%$. Their conclusion was that the gain in benefits may not justify the harm from screening.

Mammography screening is unlikely to benefit those with a life expectancy of less than 5 years as reported in Tazkarji et al's study. ${ }^{27}$ Braithwaite et a ${ }^{45}$ found that the benefits of screening decrease with increasing age and co-morbidity. Their sample of women aged 65 years or above without severe comorbidity showed only a slight improvement in life expectancy. They, too, argued that the magnitude of the benefit may not justify screening given the potential harm. Citing the Canadian National Breast Screening Study with 25 years of follow-up, the National Cancer Institute in the US concluded that the benefits of mammography screening are uncertain..$^{46}$

In summary, the overall effect of breast cancer screening in older women remains a controversial topic. Currently, the American Cancer Society suggests that women who are at an 'average risk' of developing breast cancer have an annual mammogram starting at the age of 40 years, with no specific age mentioned as the marker for discontinuation, while the USPSTF now suggests that regular screening should start from the age of 50 years and end at the age of 74 years. The Hong Kong Breast Cancer Foundation recommends that women over the age of 40 years consider undergoing a mammography every 2 years. ${ }^{47}$ A summary of the literature review of screening for breast cancer is shown in Table 3. 5,20,22,27,36-45

\section{Liver cancer screening}

There are no widely recommended tests to screen for liver cancer among the general public except for those who are at a high risk of developing the disease. Alpha-fetoprotein (AFP) and abdominal ultrasound are the two most common tests in use. Nonetheless the sensitivity and specificity levels of AFP are unsatisfactory ${ }^{48}$ This protein has also been shown to be unreliable in detecting small liver cancer.

There is hardly any evidence of the benefits of screening older people for liver cancer. Huang et $\mathrm{a}^{49}$ conducted a two-stage community screening programme (first with blood tests and then by ultrasonogram for identified high-risk cases) on a sample of 1002 people with a mean age of 68.3 years for women and men in an area where the hepatitis $C$ virus is endemic. They observed that older patients who had early-stage hepatocellular carcinoma and who were being treated had a good prognosis for survival.

Currently, the American Cancer Society offers no recommendations for liver cancer screening in the general population. Cancer Research UK recommends a liver screening test only for high-risk individuals. ${ }^{50}$ Similarly, the Hong Kong Department of Health does not recommend routine cancer screening for people at 'average risk'-only for those at high risk, such as carriers of the hepatitis $B$ and/or C viruses and those with cirrhosis. ${ }^{51}$ In summary, screening tests for liver cancer should not be performed in a routine manner but should be recommended only for people who are at a high risk of developing the disease. A summary of the literature review of screening for liver cancer is shown in Table $4{ }^{49}$

\section{Prostate cancer screening}

Prostate-specific antigen (PSA) testing, digital rectal examination, and prostate biopsy are the three main approaches usually used in combination with screening prostate cancer. ${ }^{4}$ There is no single effective and reliable test to screen for early prostate cancer in healthy men..$^{50}$ It is not uncommon for men to have some cancer cells in their prostate by the age of 80 years although only one in 25 will actually die from prostate cancer..$^{50}$ To date, the debate over PSA screening remains heated even though screening was first introduced in the late 1980s.

Konety et $\mathrm{al}^{52}$ reported the work of a 30 member panel of US experts who recommended that the initiation of screening for prostate cancer in men older than 75 years should be undertaken only after careful consideration, and that age-normed PSA values should be used to determine 'normal' levels.

Using mathematical modelling, Etzioni et a ${ }^{53}$ found that by $2000,45 \%$ to $70 \%$ of the observed decline in prostate cancer mortality could be plausibly attributed to screening. They concluded that PSA screening might account for much of the observed drop in prostate cancer mortality. Etzioni et $\mathrm{al}^{54}$ also studied the link between PSA screening and the decline in the incidence of late-stage prostate cancer. Their tested model showed that screening explained about $80 \%$ of the observed decline in the incidence of distant-stage (as opposed to locoregional stage) prostate cancer. Nonetheless the team suggested that other factors such as awareness and advances in treatment might also play certain roles.

Telesca et $\mathrm{al}^{55}$ used data derived from the 
TABLE 3. Screening for breast cancer: summary of literature review

\begin{tabular}{lllll}
\hline Study & Country & Study design & Objective(s) & Sample \\
\hline $\begin{array}{l}\text { Fillenbaum et } \\
\text { al, }{ }^{22} 2007\end{array}$ & US & $\begin{array}{l}\text { Longitudinal cohort } \\
\text { study (followed up for } \\
4-6 \text { years) }\end{array}$ & $\begin{array}{l}\text { To determine the effect } \\
\text { of health behaviours } \\
\text { such as cancer }\end{array}$ & $\begin{array}{l}\text { A representative } \\
\text { community sample of } \\
\text { those aged } \geq 71 \text { years }\end{array}$ \\
& & screening on population & $(\mathrm{n}=2230)$ from the Duke \\
& & health-related outcomes & Established Populations \\
& & & for Epidemiologic Studies \\
& & & of the Elderly
\end{tabular}

Galit et al, ${ }^{36} \quad$ Israel (first $\quad$ Systematic review of $\quad$ To determine the $\quad$ Women aged $>74$ years

2007 author) studies in MEDLINE efficacy of breast
up to August $2006 \quad$ cancer screening

Key findings / conclusion

No significant association between cancer screening and population-level health-related outcomes (as measured by functional status, self-rated health, hospitalisations, and mortality rate); disease-specific screens were useful at a personal level but not associated with population-level health

Early detection of cancer and reduction of breast cancer mortality associated with a mammography screening programme in women aged $\geq 75$ years, with reasonable life expectancy and without severe co-morbidity; data supported screening for those aged $\geq 75$ years, based on individual assessments

$\begin{array}{lll}\begin{array}{l}\text { Mo et al, }{ }^{37} \quad \text { China } \\ 2013\end{array} & \begin{array}{l}\text { Uncontrolled clinical } \\ \text { trial (2008-2012) }\end{array} & \begin{array}{l}\text { To evaluate the } \\ \text { outcomes of using } \\ \text { individual and } \\ \text { combined breast } \\ \text { cancer screening (CBE, } \\ \text { mammographies, and } \\ \text { ultrasound) }\end{array}\end{array}$

Women aged 35-74 years in a county of Shanghai $(n=14464)$

The sensitivity of using CBE, ultrasound, or mammogram alone was $61.4 \%, 53.7 \%$, and $67.3 \%$, respectively; the sensitivity level improved with the combined use of mammogram and ultrasound; mammography alone for women aged $>70$ years with positive CBE results would save on the cost of ultrasonography without losing the effectiveness of screening

\section{Mandelblatt et US}

$\mathrm{al}^{42} 2009$
Simulation modelling

\section{To evaluate the} 20 mammography screening strategies with different initiation and cessation ages and screening intervals using 6 established models of cancer incidence and mortality trends in the US

\begin{tabular}{|c|c|c|c|}
\hline $\begin{array}{l}\text { Gøtzsche and } \\
\text { Nielsen, }{ }^{43} 2011\end{array}$ & $\begin{array}{l}\text { Denmark } \\
\text { (first author) }\end{array}$ & $\begin{array}{l}\text { Systematic review } \\
\text { (Cochrane) with meta- } \\
\text { analysis of } 8 \text { included } \\
\text { RCTs }\end{array}$ & $\begin{array}{l}\text { To examine the effect } \\
\text { of mammography } \\
\text { screening in terms } \\
\text { of mortality and } \\
\text { morbidity using papers } \\
\text { in PubMed up to } \\
\text { November } 2008\end{array}$ \\
\hline $\begin{array}{l}\text { Broeders et } \\
\text { al, }{ }^{38} 2012\end{array}$ & $\begin{array}{l}\text { The } \\
\text { Netherlands } \\
\text { (first author) }\end{array}$ & $\begin{array}{l}\text { Systematic review of } \\
\text { observational studies } \\
\text { and meta-analysis } \\
\text { of incidence-based } \\
\text { mortality and case- } \\
\text { controlled studies }\end{array}$ & $\begin{array}{l}\text { To evaluate the impact } \\
\text { of mammography } \\
\text { screening on mortality } \\
\text { rates for breast cancer } \\
\text { in Europe using articles } \\
\text { in PubMed up to } \\
\text { February } 2011\end{array}$ \\
\hline
\end{tabular}

A cohort of women born in 1960 and followed up from age 25 years and throughout their lifetime

Women who had not had breast cancer in 2 groups $(\mathrm{n}=600000)$ : with and without mammography screening; however, only one trial included women aged $45-69$ years; most included RCTs had an age range of 45-64 years

Studies that included an analysis of a group aged between 50 and 69 years
Biennial screening achieves a mean of $81 \%$ of the benefit of annual screening, but with less harm ( $50 \%$ reduction in the number of false-positive cases); if the cessation age was set at $>69$ years, a slight reduction in mortality was observed but with increased age, overdiagnoses also increased

Screening led to a mortality reduction of $15 \%$ but an over-diagnosis and overtreatment rate of $30 \%$; It is therefore questionable whether screening does more good than harm

Reduction in breast cancer mortality was $38 \%-48 \%$ for women who were actually screened; valid observational designs should have adequately followed up on individual data, including a woman's history of screening and the cause of her death; the current controversy over breast cancer screening was related to the use of inappropriate methods that were incapable of revealing the true effect of screening

7-9 Women saved/1000 women screened biennially from age 50-51 till 68-69 years and followed up for another 10 years; 4 women in this group would be over-diagnosed and 200 women would have a false-negative result; the benefit of population-based mammography screening was greater than over-diagnosis 
TABLE 3. (cont'd)

\begin{tabular}{|c|c|c|c|c|c|}
\hline Study & Country & Study design & Objective(s) & Sample & Key findings / conclusion \\
\hline $\begin{array}{l}\text { Tejada et al, }{ }^{40} \\
2015\end{array}$ & US & Simulation modelling & $\begin{array}{l}\text { To examine the effect of } \\
\text { breast cancer screening } \\
\text { policies for women } \\
\text { aged } \geq 65 \text { years }\end{array}$ & $\begin{array}{l}\text { Over } 1 \text { million pieces } \\
\text { of de-identified data } \\
\text { from the Breast Cancer } \\
\text { Surveillance Consortium } \\
\text { (with data from } 7 \\
\text { mammography registries) } \\
\text { representative of the } \\
\text { female population aged } \\
\geq 65 \text { years in the country }\end{array}$ & $\begin{array}{l}\text { Annual screening from age } 65-80 \text { years } \\
\text { was found to be the most effective } \\
\text { cancer screening policy in that it } \\
\text { increased survival rates and minimised } \\
\text { breast cancer mortality }\end{array}$ \\
\hline $\begin{array}{l}\text { Lansdorp- } \\
\text { Vogelaar et } \\
\text { al, }^{20} 2014\end{array}$ & US & $\begin{array}{l}\text { Collaborative } \\
\text { modelling using } 7 \\
\text { well-established } \\
\text { cancer simulation } \\
\text { models }\end{array}$ & $\begin{array}{l}\text { To investigate the } \\
\text { harms and benefits of } \\
\text { cancer screening by } \\
\text { age and co-morbidity } \\
\text { to inform screening } \\
\text { cessation (including } \\
\text { mammograms, faecal } \\
\text { immunochemical tests, } \\
\text { and prostate-specific } \\
\text { antigen tests) }\end{array}$ & $\begin{array}{l}\text { Cohorts aged } 66-90 \\
\text { years in } 2010 \text { with no, } \\
\text { mild, moderate, or severe } \\
\text { co-morbidity; each cohort } \\
\text { was compared with an } \\
\text { average-health cohort }\end{array}$ & $\begin{array}{l}\text { Women with no, mild, moderate, or } \\
\text { severe co-morbidities could benefit } \\
\text { from screening until the ages of } 76-78 \text {, } \\
74,72 \text {, and } 66 \text {, respectively, and still } \\
\text { have similar levels of harm and benefit } \\
\text { as average-health individuals up to } \\
\text { age } 74 \text { years; estimates of harms and } \\
\text { benefits by co-morbidity could help } \\
\text { doctors and patients to decide on } \\
\text { when to cease screening }\end{array}$ \\
\hline $\begin{array}{l}\text { de Glas et al, }{ }^{5} \\
2014\end{array}$ & $\begin{array}{l}\text { The } \\
\text { Netherlands }\end{array}$ & $\begin{array}{l}\text { Retrospective study } \\
\text { using a national } \\
\text { cancer registry } \\
\text { database }\end{array}$ & $\begin{array}{l}\text { To assess breast cancer } \\
\text { incidence (early [stages } \\
\text { I, II, or ductal in-situ] } \\
\text { and advanced [stages } \\
\text { III, IV] stages) pre- and } \\
\text { post-implementation } \\
\text { of a mass screening } \\
\text { programme that had } \\
\text { been extended to the } \\
\text { upper age of } 75 \text { years } \\
\text { in } 1998\end{array}$ & $\begin{array}{l}\text { Women aged } 70-75 \text { years } \\
(n=25414) \text { diagnosed } \\
\text { with breast cancer } \\
\text { between } 1995 \text { and } 2011\end{array}$ & $\begin{array}{l}\text { An increase of } 114.2 / 100000 \text { cases of } \\
\text { early-stage tumours and a decrease of } \\
6.8 / 100000 \text { cases of advanced-stage } \\
\text { tumours post-implementation; over- } \\
\text { diagnoses implied that the programme } \\
\text { was of limited effectiveness }\end{array}$ \\
\hline $\begin{array}{l}\text { Parvinen et } \\
\text { al, }^{44} 2015\end{array}$ & Finland & $\begin{array}{l}\text { Retrospective } \\
\text { cohort study using } \\
\text { the Finnish Cancer } \\
\text { Registry }\end{array}$ & $\begin{array}{l}\text { To examine the effect } \\
\text { of a mammography } \\
\text { screening programme } \\
\text { in the city of Turku, } \\
\text { Finland, by comparing } \\
\text { mortality rates with } \\
\text { other regions with } \\
\text { different screening } \\
\text { policies }\end{array}$ & $\begin{array}{l}40.7 \text { Million women aged } \\
40-84 \text { years for the period } \\
1976-2009 \text { (pre-screening } \\
\text { era: } 1976-1986)\end{array}$ & $\begin{array}{l}\text { >20\% Reduction in mortality found } \\
\text { (a) among women aged } 60-74 \text { years } \\
\text { compared with Helsinki, and (ii) in } \\
\text { women aged } 75-84 \text { years at death } \\
\text { compared with the rest of Finland; } \\
\text { findings supported breast cancer } \\
\text { screening targeted at women aged } \\
50-74 \text { years }\end{array}$ \\
\hline $\begin{array}{l}\text { Sanderson et } \\
a l,{ }^{41} 2015\end{array}$ & US & $\begin{array}{l}\text { Retrospective study } \\
\text { using Medicare claims } \\
\text { data (1995-2009) } \\
\text { from the Surveillance, } \\
\text { Epidemiology, } \\
\text { and End Results } \\
\text { programme }\end{array}$ & $\begin{array}{l}\text { To explore whether } \\
\text { age and race } \\
\text { affect the results } \\
\text { of mammography } \\
\text { screening on mortality } \\
\text { among women aged } \\
69-84 \text { years }\end{array}$ & $\begin{array}{l}\text { A total of } 64384 \text { ( } 4886 \\
\text { black and } 59498 \text { white) } \\
\text { women with a primary } \\
\text { breast cancer diagnosis } \\
\text { who had an annual or } \\
\text { biennial screening } 4 \\
\text { years prior to diagnosis; } \\
\text { followed up for } 10 \text { years }\end{array}$ & $\begin{array}{l}\text { 10-Year mortality risks were } 3.3 \text { times } \\
\text { higher in whites and } 2.2 \text { times higher } \\
\text { in blacks with no or irregular screening } \\
\text { compared to annual screening }\end{array}$ \\
\hline $\begin{array}{l}\text { Tazkarji et al, }{ }^{27} \\
2016\end{array}$ & $\begin{array}{l}\text { Canada (first } \\
\text { author) }\end{array}$ & $\begin{array}{l}\text { A methodical } \\
\text { approach to searching } \\
\text { the literature (2006- } \\
\text { July 2016) }\end{array}$ & $\begin{array}{l}\text { To guide family doctors } \\
\text { in devising screening } \\
\text { and treatment plans for } \\
\text { older patients }\end{array}$ & Not applicable & $\begin{array}{l}\text { Screening mammography most likely } \\
\text { unable to benefit women with }<5 \\
\text { years of life expectancy; needed to } \\
\text { consider age, life expectancy, co- } \\
\text { morbidities, functional status, risks } \\
\text { and benefits, and patient preferences } \\
\text { when recommending preventive health } \\
\text { measures to patients }\end{array}$ \\
\hline $\begin{array}{l}\text { Braithwaite et } \\
\text { al, }{ }^{45} 2016\end{array}$ & $\begin{array}{l}\text { US (first } \\
\text { author) }\end{array}$ & Systematic review & $\begin{array}{l}\text { To review studies (in } \\
\text { MEDLINE and EMBASE } \\
\text { published from } 1980 \\
\text { to } 2013 \text { ) that examined } \\
\text { the benefits and harms } \\
\text { of mammography } \\
\text { screening for women } \\
\text { aged } \geq 65 \text { years }\end{array}$ & Not applicable & $\begin{array}{l}\text { Women aged } \geq 65 \text { years without } \\
\text { severe co-morbidity might have a } \\
\text { slightly improved life expectancy from } \\
\text { screening; benefits decreased with } \\
\text { increases in age and co-morbidity } \\
\text { levels; the magnitude of the benefit } \\
\text { might not justify screening given the } \\
\text { potential harms }\end{array}$ \\
\hline
\end{tabular}


TABLE 4. Screening for liver cancer: summary of literature review ${ }^{49}$

\begin{tabular}{|c|c|c|c|c|c|}
\hline Study & Country & Study design & Objective & Sample & Key findings / conclusion \\
\hline $\begin{array}{l}\text { Huang et } \\
\text { al, }{ }^{49} 2011\end{array}$ & Taiwan & $\begin{array}{l}\text { Uncontrolled } \\
\text { clinical trial }\end{array}$ & $\begin{array}{l}\text { To determine whether a } \\
\text { hepatocellular carcinoma } \\
\text { 2-stage screening } \\
\text { programme could reduce } \\
\text { mortality among elderly } \\
\text { patients }\end{array}$ & $\begin{array}{l}\text { Participants }(n=1002) \\
\text { from community; mean } \\
\text { age } 68.3 \text { for females } \\
\text { and } 65.3 \text { years for } \\
\text { males; followed up for } \\
4 \text { years post-screening }\end{array}$ & $\begin{array}{l}\text { Alpha-fetoprotein and platelet count are } \\
\text { feasible screening methods to identify } \\
\text { risk among the elderly; good prognosis of } \\
\text { survival observed in elderly patients at the } \\
\text { early stage of hepatocellular carcinoma who } \\
\text { accepted curative treatment }\end{array}$ \\
\hline
\end{tabular}

Surveillance, Epidemiology, and End Results (SEER) registry of the National Cancer Institute in the US to examine the increase and subsequent decline in the incidence of prostate cancer after the adoption of PSA screening, and arrived at the opposite conclusion. They maintained that the disease would not have continued to increase in incidence in the absence of PSA screening. Also using the SEER data, Welch and Albertsen ${ }^{56}$ used age-specific population estimates from the US Census data to determine the excess or deficit in the number of men diagnosed and treated each year after 1986. Since 1986, an estimated additional 1.3 million men were diagnosed and more than 1 million of them were treated. They concluded that most of the excess incidence must be the result of over-diagnosis.

Two large-scale RCTs published in 2009the European Randomized Study of Screening for Prostate $\mathrm{Cancer}^{57}$ and the US PLCO cancer screening trial $^{58}$ - produced conflicting results on screening for prostate cancer with PSA testing, providing fuel for further debate.

Jemal et $\mathrm{a}^{59}$ conducted an interesting study that examined changes in the incidence of stagespecific prostate cancer and PSA screening rates for the period 2005 to 2012 using the US National Cancer Institute database. Both the incidence of early-stage prostate cancer and rates of PSA screening had declined, coinciding with the 2012 USPSTF recommendation to omit PSA screening from routine primary care. Nonetheless, the authors also recommended a longer follow-up period to ascertain whether these decreases were indeed associated with mortality trends. Thus, whether reduced screening would lead to reductions in over-diagnoses or to missed opportunities for early detection remains an open question.

The American Cancer Society states that a screening test should not be offered to men who do not have any symptoms of prostate cancer and who have a life expectancy of about 10 more years or less, because of its slow-growing prognosis. The USPSTF and the American Academy of Family Physicians do not recommend the use of the PSA test to screen for prostate cancer, as there is little evidence to show that the benefits outweigh the harm. They argue against screening for men 75 years of age and older because of a lack of evidence to support screening.

In brief, views about the desirability of prostate cancer screening are polarised, and much confusion over the issue remains. ${ }^{60}$ Observational evidence to date has not always supported the efficacy of PSA screening in reducing mortality; rather, a growing body of observational evidence points to the overdiagnosis and over-treatment of prostate cancer triggered by PSA testing. ${ }^{61}$ Randomised trials have produced conflicting results. Thus, the efficacy of prostate cancer screening for old men remains a point of contention. A summary of the literature review of screening for prostate cancer is shown in Table $5 .{ }^{20,27,52-59}$

\section{To screen or not to screen older people}

To screen or not to screen older people for common types of cancer remains controversial, especially for people over the age of 75 years. Screening may reduce the risk that individuals will develop a condition or its complications, but it may not guarantee protection. Most of the papers and guidelines suggested that screening has to be individualised for this particular age-group. Even though the risk of cancer increases with age, it should not be the only factor taken into account when making decisions about screening. Routine cancer screening does not benefit those with a limited life expectancy. ${ }^{62}$ Estimating life expectancy will help guide decisionmaking for preventive screening and treatment plans. ${ }^{27}$ Because life expectancy varies in relation to co-morbidity status, taking co-morbidity-adjusted life expectancy into consideration may be helpful to physicians. ${ }^{35}$

In any screening programme, there is an irreducible minimum of false-positive and falsenegative results. ${ }^{23}$ The feelings and overall health status of the patient also need to be considered. It may be appropriate to screen patients with a life expectancy sufficiently long to experience the potential benefits of screening. Personalised 
TABLE 5. Screening for prostate cancer: summary of literature review $20,27,52-59$

\begin{tabular}{|c|c|c|c|c|c|}
\hline Study & Country & Study design & Objective & Sample & Key findings / conclusion \\
\hline $\begin{array}{l}\text { Konety et al, }, 52 \\
2008\end{array}$ & US & $\begin{array}{l}\text { Review of the } \\
\text { literature and expert } \\
\text { panel discussions } \\
\text { to arrive at a } \\
\text { consensus }\end{array}$ & $\begin{array}{l}\text { To develop a consensus } \\
\text { recommendations } \\
\text { for prostate cancer } \\
\text { screening and } \\
\text { management }\end{array}$ & $\begin{array}{l}\text { An expert panel } \\
\text { consisting of } 30 \\
\text { multidisciplinary } \\
\text { health are providers } \\
\text { (physicians from related } \\
\text { specialties, nurses, } 1 \\
\text { patient representative, } \\
\text { and } 1 \text { attorney) in the } \\
\text { state of lowa }\end{array}$ & $\begin{array}{l}\text { The panel supported using greater } \\
\text { discretion in screening for prostate } \\
\text { cancer in the older population; also } \\
\text { agreed that there was a greater need for } \\
\text { patient counselling with regard to the } \\
\text { harms and benefits of screening after } 75 \\
\text { years of age }\end{array}$ \\
\hline
\end{tabular}

$\begin{array}{ll}\text { Etzioni et al, }{ }^{53} \text { US } & \begin{array}{l}\text { Simulation } \\ \text { modelling }\end{array} \\ 2008 & \end{array}$

$\begin{array}{ll}\text { Etzioni et al, }{ }^{54} \text { US } & \begin{array}{l}\text { Simulation } \\ \text { modelling }\end{array} \\ 2008 & \end{array}$

\begin{tabular}{|c|c|c|c|}
\hline $\begin{array}{l}\text { Welch and } \\
\text { Albertsen, }{ }^{56} \\
2009\end{array}$ & US & $\begin{array}{l}\text { Retrospective data } \\
\text { analysis }\end{array}$ & $\begin{array}{l}\text { To estimate the number } \\
\text { of men affected in } \\
\text { terms of diagnosis and } \\
\text { treatment after the } \\
\text { introduction of PSA } \\
\text { screening }\end{array}$ \\
\hline $\begin{array}{l}\text { Schröder } \\
\text { et al, }{ }^{77} \text { for } \\
\text { the ERSPC } \\
\text { Investigators, } \\
2009\end{array}$ & $\begin{array}{l}\text { Finland, } \\
\text { Sweden, } \\
\text { Italy, The } \\
\text { Netherlands, } \\
\text { Belgium, } \\
\text { Spain, } \\
\text { Switzerland }\end{array}$ & $\begin{array}{l}\text { Randomised } \\
\text { multicentre trial } \\
\text { initiated in the } \\
\text { 1990s }\end{array}$ & $\begin{array}{l}\text { To determine the effect } \\
\text { of screening with a PSA } \\
\text { test on death rates from } \\
\text { prostate cancer }\end{array}$ \\
\hline $\begin{array}{l}\text { Andriole et } \\
\text { al, }{ }^{58} \text { for the } \\
\text { PLCO cancer } \\
\text { screening trial, } \\
2009\end{array}$ & US & $\begin{array}{l}\text { Randomised } \\
\text { controlled trial }\end{array}$ & $\begin{array}{l}\text { To investigate the } \\
\text { effect of screening with } \\
\text { PSA test and digital } \\
\text { rectal examinations on } \\
\text { mortality rates from } \\
\text { prostate cancer }\end{array}$ \\
\hline
\end{tabular}

Telesca et al, 55 US 2008

Simulation modelling
To quantify the impact of PSA screening on the decline in mortality from prostate cancer during the 1990s
Used 2 mathematical models to project mortality rates among men aged 50-84 years with or without PSA screening between 1980 and 2000

Simulated life histories

To examine the link between PSA screening and the decline in the incidence of distantstage prostate cancer (the authors classified pathological stages into clinical stages of 'locoregional' or 'distant' cancer progression)

To estimate the lead time in diagnoses associated with PSA testing years between 1980 and 2000; PSA testing was superimposed on a background of natural histories and clinical diagnoses of prostate cancer without screening
Data from 9 SEER areas in the US

Projected that $45 \%-70 \%$ of the observed decline in prostate cancer mortality might be attributable to screening; also suggested that other issues such as changes in treatment practices might also play a role in improved outcomes

The tested model showed that PSA for US men aged $50-84$ screening explained around $80 \%$ of the observed decline in the incidence of distant-stage prostate cancer; other factors including awareness and advances in treatment might also play certain roles

Data from SEER (1986 as the base year-the year before PSA screening was introduced) plus US census data for estimating the excess number of men diagnosed and treated each year after 1986, up to 2005

Age $50-74$ years ( $n=182$ 000); screening group: offered PSA screening about once every 4 years and control group: did not receive screening

Participants ( $n=76693)$ divided into annual screening group $(n=38343)$ and usual care group $(\mathrm{n}=38350)$ followed up from 19932001
4.59 Years of lead time for whites and 6.78 years for blacks with a corresponding estimated fairly flat trend of prostate cancer incidence after the introduction of PSA screening; the results implied that the incidence of prostate cancer would level off in line with changes in prostate care in the absence of PSA screening

In considering the incidence trend in the US for the last 2 decades, an estimated additional 1305600 men were diagnosed with prostate cancer, and 1004800 of those were treated; the majority of the additional 1 million men did not benefit from early detection

1410 Men would be required to be screened and another 48 men treated in order to prevent 1 prostate cancer death; screening by PSA test reduced deaths by $20 \%$ but was associated with a high risk of over-diagnosis

After 7 years of follow-up, the incidence of death from prostate cancer in the annual screening group $=50 / 10000$ person-years, and in the usual care group $=44 / 10000$ person-years; the death rate from prostate cancer was very low and there was no significant difference between groups

Abbreviations: ERSPC = European Randomized study of Screening for Prostate Cancer; PLCO = Prostate, Lung, Colorectal, and Ovarian; PSA = prostatespecific antigen; SEER = Surveillance, Epidemiology, and End Results 
TABLE 5. (cont'd)

\begin{tabular}{|c|c|c|c|c|c|}
\hline Study & Country & Study design & Objective & Sample & Key findings / conclusion \\
\hline $\begin{array}{l}\text { Lansdorp- } \\
\text { Vogelaar et } \\
\text { al, }^{20} 2014\end{array}$ & US & $\begin{array}{l}\text { Collaborative } \\
\text { modelling using } 7 \\
\text { well-established } \\
\text { cancer simulation } \\
\text { models }\end{array}$ & $\begin{array}{l}\text { To investigate the } \\
\text { harms and benefits of } \\
\text { cancer screening by } \\
\text { age and co-morbidity } \\
\text { to inform screening } \\
\text { cessation (including } \\
\text { mammograms, the } \\
\text { faecal immunochemical } \\
\text { test, and the PSA test) }\end{array}$ & $\begin{array}{l}\text { Cohorts aged } 66-90 \\
\text { years in } 2010 \text { with no, } \\
\text { mild, moderate, or } \\
\text { severe co-morbidity; } \\
\text { each cohort was } \\
\text { compared with an } \\
\text { average-health cohort }\end{array}$ & $\begin{array}{l}\text { Older people with no, mild, moderate, } \\
\text { or severe co-morbidities could benefit } \\
\text { from screening until the ages of } 76-78 \text {, } \\
74,72 \text {, and } 66 \text {, respectively, and still } \\
\text { have similar levels of harm and benefit as } \\
\text { average-health individuals up to age } 74 \\
\text { years; estimates of harms and benefits } \\
\text { by co-morbidity could help doctors and } \\
\text { patients to decide on when to cease } \\
\text { screening }\end{array}$ \\
\hline $\begin{array}{l}\text { Jemal et al, }{ }^{59} \\
2015\end{array}$ & US & $\begin{array}{l}\text { Ecological study } \\
\text { (retrospective data } \\
\text { analysis) }\end{array}$ & $\begin{array}{l}\text { To examine changes } \\
\text { in prostate cancer } \\
\text { incidence and PSA } \\
\text { screening rates with } \\
\text { regard to the } 2008 \\
\text { and } 2012 \text { USPSTF } \\
\text { recommendations }\end{array}$ & $\begin{array}{l}\text { Data from SEER } \\
\text { registries plus data } \\
\text { from men aged } \\
\geq 50 \text { years without } \\
\text { prostate cancer who } \\
\text { responded to the } \\
2005,2008,2010 \text {, and } \\
2013 \text { National Health } \\
\text { Interview Survey were } \\
\text { used to determine the } \\
\text { rate of self-reported } \\
\text { PSA testing in the } \\
\text { previous year }\end{array}$ & $\begin{array}{l}\text { The incidence of early-stage prostate } \\
\text { cancer and PSA screening rates have } \\
\text { both declined and coincided with the } \\
2012 \text { USPSTF recommendation not to } \\
\text { conduct PSA tests in routine primary } \\
\text { care for men; a longer follow-up period } \\
\text { was needed to see whether these } \\
\text { decreases were associated with mortality }\end{array}$ \\
\hline $\begin{array}{l}\text { Tazkarji et al, }{ }^{27} \\
2016\end{array}$ & $\begin{array}{l}\text { Canada (first } \\
\text { author) }\end{array}$ & $\begin{array}{l}\text { A methodical } \\
\text { approach to } \\
\text { searching the } \\
\text { literature (2006- } \\
\text { July 2016) }\end{array}$ & $\begin{array}{l}\text { To guide family doctors } \\
\text { in devising screening } \\
\text { and treatment plans for } \\
\text { older patients }\end{array}$ & Not applicable & $\begin{array}{l}\text { Need to consider age, life expectancy, } \\
\text { co-morbidities, functional status, risks } \\
\text { and benefits, and patient preferences } \\
\text { when recommending preventive health } \\
\text { measures to patients }\end{array}$ \\
\hline
\end{tabular}

Abbreviations: PSA = prostate-specific antigen; SEER = Surveillance, Epidemiology, and End Results; USPSTF = US Preventive Services Task Force

consideration might benefit older people if the positive impacts can outweigh the negative, even for the oldest-old.

\section{Conclusion}

Cancer is common in the older population and, for them, the benefits of screening for common types of cancer remain controversial. The evidence is strongest for the efficacy of colorectal cancer screening, even for older people aged 75 years and beyond. Low-dose CT for screening for lung cancer has benefits for heavy smokers. Liver cancer screening is recommended only for those at high risk of developing the disease. The evidence for screening older people for breast cancer is conflicting; as is the evidence for the effectiveness of PSA tests for screening for prostate cancer. Although some screening tests can bring certain benefits, other factors related to advancing age may be present, such as co-morbidities that may cause harm and would eventually outweigh the benefits of cancer screening. More research is indeed needed to understand the relationship between cancer and ageing, and also the risks and benefits of cancer screening for older people, to ultimately promote good health and functional longevity.

\section{References}

1. World Health Organization. Cancer fact sheet. February 2017. Available from: http://www.who.int/mediacentre/ factsheets/fs297/en/. Accessed 15 Jun 2017.

2. Ferlay J, Soerjomataram I, Dikshit R, et al. Cancer incidence and mortality worldwide: sources, methods and major patterns in GLOBOCAN 2012. Int J Cancer 2015;136:E359-86.

3. Ngan KC. Overview of Hong Kong cancer statistics of 2014. November 2016. Available from: http://www3.ha.org.hk/ cancereg/pdf/overview/Summary\%20of\%20CanStat\%20 2014.pdf. Accessed 15 Jun 2017.

4. Albert RH, Clark MM. Cancer screening in the older patient. Am Fam Physician 2008;78:1369-74.

5. de Glas NA, de Craen AJ, Bastiaannet E, et al. Effect of implementation of the mass breast cancer screening programme in older women in the Netherlands: population based study. BMJ 2014;349:g5410.

6. National Cancer Institute. International cancer screening network. 2014. Available from: http://appliedresearch. cancer.gov/icsn/. Accessed 2 Oct 2016.

7. Turkoz FP, Tokluoglu S, Durnali AG, et al. Cancer evaluation in geriatric population: a single institution experience. Int J Hematol Oncol 2013;23:28-33.

8. Craft M. Cancer screening in the older adult: issues and concerns. Nurs Clin North Am 2014;49:251-61.

9. Arksey H, O’Malley L. Scoping studies: towards a methodological framework. Int J Soc Res Methodol 2005;8:19-32.

10. Wilson JA. Colon cancer screening in the elderly: when do we stop? Trans Am Clin Climatol Assoc 2010;121:94-103.

11. Quarini C, Gosney M. Review of the evidence for a colorectal cancer screening programme in elderly people. Age Ageing 2009;38:503-8.

12. Meester RG, Doubeni CA, Lansdorp-Vogelaar I, et al. Colorectal cancer deaths attributable to nonuse of screening 
in the United States. Ann Epidemiol 2015;25:208-13.

13. Brenner H, Altenhofen L, Stock C, Hoffmeister M. Expected long-term impact of the German screening colonoscopy programme on colorectal cancer prevention: analyses based on 4,407,971 screening colonoscopies. Eur J Cancer 2015;51:1346-53.

14. Brenner H, Altenhofen L, Stock C, Hoffmeister M. Prevention, early detection, and overdiagnosis of colorectal cancer within 10 years of screening colonoscopy in Germany. Clin Gastroenterol Hepatol 2015;13:717-23.

15. Rozen P, Shabtai EI, Liphshitz I, Barchana M. Risk for colorectal cancer in elderly persons and possible methodologies for their screening. Eur J Gastroenterol Hepatol 2011;23:431-7.

16. Maheshwari S, Patel T, Patel P. Screening for colorectal cancer in elderly persons: who should we screen and when can we stop? J Aging Health 2008;20:126-39.

17. Kahi CJ, Azzouz F, Juliar BE, Imperiale TF. Survival of elderly persons undergoing colonoscopy: implications for colorectal cancer screening and surveillance. Gastrointest Endosc 2007;66:544-50.

18. van Hees F, Habbema JD, Meester RG, Lansdorp-Vogelaar I, Van Ballegooijen M, Zauber AG. Should colorectal cancer screening be considered in elderly persons without previous screening? A cost-effectiveness analysis. Ann Intern Med 2014;160:750-9.

19. van Hees F, Saini SD, Lansdorp-Vogelaar I, et al. Personalizing colonoscopy screening for elderly individuals based on screening history, cancer risk, and comorbidity status could increase cost effectiveness. Gastroenterology 2015;149:1425-37.

20. Lansdorp-Vogelaar I, Gulati R, Mariotto AB, et al. Personalizing age of cancer screening cessation based on comorbid conditions: model estimates of harms and benefits. Ann Intern Med 2014;161:104-12.

21. Gross CP, Soulos PR, Ross JS, et al. Assessing the impact of screening colonoscopy on mortality in the medicare population. J Gen Intern Med 2011;26:1441-9.

22. Fillenbaum GG, Burchett BM, Kuchibhatla MN, Cohen HJ, Blazer DG. Effect of cancer screening and desirable health behaviors on functional status, self-rated health, health service use and mortality. J Am Geriatr Soc 2007;55:66-74.

23. Pasetto LM, Monfardini S. Colorectal cancer screening in elderly patients: when should be more useful? Cancer Treat Rev 2007;33:528-32.

24. National Cancer Institute. Tests to detect colorectal cancer and polyps. 2016. Available from: http://www.cancer.gov/ types/colorectal/screening-fact-sheet. Accessed 2 Oct 2016.

25. American Cancer Society. Guidelines for the early detection of cancer. 2016. Available from: http://www.cancer.org/ healthy/findcancerearly/cancerscreeningguidelines/ american-cancer-society-guidelines-for-the-earlydetection-of-cancer. Accessed 2 Oct 2016.

26. US Preventive Services Task Force. Colorectal cancer: screening. 2016. Available from: http:// www.uspreventiveservicestaskforce.org/Page/ Document/UpdateSummaryFinal/colorectal-cancerscreening2?ds=1\&s=Colorectal\%20Cancer:\%20Screening. Accessed 2 Oct 2016.

27. Tazkarji B, Lam R, Lee S, Meiyappan S. Approach to preventive care in the elderly. Can Fam Physician 2016;62:717-21.
28. Hong Kong Anti-Cancer Society. Cancer screening, early detection and prevention guidelines for health professionals. 2011. Available from: https://www.hkacs. org.hk/ufiles/CancerScreeningprofessionals_2ndediti on_1.pdf. Accessed 2 Oct 2016.

29. Detterbeck FC, Mazzone PJ, Naidich DP, Bach PB. Screening for lung cancer: Diagnosis and management of lung cancer, 3rd ed: American College of Chest Physicians evidence-based clinical practice guidelines. Chest 2013;143(5 Suppl): e78S-92S.

30. Humphrey LL, Deffebach M, Pappas M, et al. Screening for lung cancer with low-dose computed tomography: a systematic review to update the US Preventive Services Task Force recommendation. Ann Intern Med 2013;159:411-20.

31. Oken MM, Hocking WG, Kvale PA, et al. Screening by chest radiograph and lung cancer mortality: the Prostate, Lung, Colorectal, and Ovarian (PLCO) randomized trial. JAMA 2011;306:1865-73.

32. National Lung Screening Trial Research Team; Aberle DR, Adams AM, Berg CD, et al. Reduced lung-cancer mortality with low-dose computed tomographic screening. N Engl J Med 2011;365:395-409.

33. McMahon PM, Meza R, Plevritis SK, et al. Comparing benefits from many possible computed tomography lung cancer screening programs: extrapolating from the national lung screening trial using comparative modeling. PLoS One 2014;9:e99978.

34. Moyer VA, US Preventive Services Task Force. Screening for lung cancer: U.S. Preventive Services Task Force recommendation statement. Ann Intern Med 2014;160: 330-8.

35. Cho H, Klabunde CN, Yabroff KR, et al. Comorbidityadjusted life expectancy: a new tool to inform recommendations for optimal screening strategies. Ann Intern Med 2013;159:667-76.

36. Galit W, Green MS, Lital KB. Routine screening mammography in women older than 74 years: a review of the available data. Maturitas 2007;57:109-19.

37. Mo M, Liu GY, Zheng Y, et al. Performance of breast cancer screening methods and modality among Chinese women: a report from a society-based breast screening program (SBSP) in Shanghai. Springerplus 2013;2:276.

38. Broeders M, Moss S, Nyström L, et al. The impact of mammographic screening on breast cancer mortality in Europe: a review of observational studies. J Med Screen 2012;19 Suppl 1:14-25.

39. Paci E; EUROSCREEN Working Group. Summary of the evidence of breast cancer service screening outcomes in Europe and first estimate of the benefit and harm balance sheet. J Med Screen 2012;19 Suppl 1:5-13.

40. Tejada JJ, Ivy JS, Wilson JR, Ballan MJ, Diehl KM, Yankaskas BC. Combined DES/SD model of breast cancer screening for older women, I: natural-history simulation. IIE Trans 2015;47:600-19.

41. Sanderson M, Levine RS, Fadden MK, et al. Mammography screening among the elderly: a research challenge. Am J Med 2015;128:1362.e7-14.

42. Mandelblatt JS, Cronin KA, Bailey S, et al. Effects of mammography screening under different screening schedules: model estimates of potential benefits and harms. Ann Intern Med 2009;151:738-47.

43. Gøtzsche PC, Nielsen M. Screening for breast cancer with mammography. Cochrane Database Syst Rev 
2011;(1):CD001877.

44. Parvinen I, Heinävaara S, Anttila A, Helenius H, Klemi P, Pylkkänen L. Mammography screening in three Finnish residential areas: comprehensive population-based study of breast cancer incidence and incidence-based mortality 1976-2009. Br J Cancer 2015;112:918-24.

45. Braithwaite D, Walter LC, Izano M, Kerlikowske K. Benefits and harms of screening mammography by comorbidity and age: a qualitative synthesis of observational studies and decision analyses. J Gen Intern Med 2016;31:561-72.

46. National Cancer Institute. Breast cancer screening (PDQ)-health professional version. June 2017. Available from: https://www.cancer.gov/types/breast/hp/breastscreening-pdq/. Accessed 21 Jun 2017.

47. Hong Kong Breast Cancer Foundation. Breast selfexamination. Available from: https://www.hkbcf.org/ content.php?cid=20\&tid=3\&lang=eng. Accessed 29 Aug 2017.

48. Zhao YJ, Ju Q, Li GC. Tumor markers for hepatocellular carcinoma. Mol Clin Oncol 2013;1:593-8.

49. Huang YC, Huang CF, Chang KC, et al. Community-based screening for hepatocellular carcinoma in elderly residents in a hepatitis B- and C-endemic area. J Gastroenterol Hepatol 2011;26:129-34.

50. Cancer Research UK. Liver cancer. 2016. Available from: http://www.cancerresearchuk.org/about-cancer/livercancer/getting-diagnosed/screening. Accessed 15 Jun 2017.

51. Department of Health. Liver cancer: prevention and screening. Available from: http://www.chp.gov.hk/files/ pdf/7_liver_cancer_prevention_and_screening_eng.pdf. Accessed 29 Aug 2017.

52. Konety BR, Sharp VJ, Raut H, Williams RD. Screening and management of prostate cancer in elderly men: the Iowa Prostate Cancer Consensus. Urology 2008;71:511-4.

53. Etzioni R, Tsodikov A, Mariotto A, et al. Quantifying the role of PSA screening in the US prostate cancer mortality decline. Cancer Causes Control 2008;19:175-81.

54. Etzioni R, Gulati R, Falcon S, Penson DF. Impact of PSA screening on the incidence of advanced stage prostate cancer in the United States: a surveillance modeling approach. Med Decis Making 2008;28:323-31.

55. Telesca D, Etzioni R, Gulati R. Estimating lead time and overdiagnosis associated with PSA screening from prostate cancer incidence trends. Biometrics 2008;64:10-9.

56. Welch HG, Albertsen PC. Prostate cancer diagnosis and treatment after the introduction of prostate-specific antigen screening: 1986-2005. J Natl Cancer Inst 2009;101:1325-9.

57. Schröder FH, Hugosson J, Roobol MJ, et al. Screening and prostate-cancer mortality in a randomized European study. N Engl J Med 2009;360:1320-8.

58. Andriole GL, Crawford ED, Grubb RL 3rd, et al. Mortality results from a randomized prostate-cancer screening trial. N Engl J Med 2009;360:1310-9.

59. Jemal A, Fedewa SA, Ma J, et al. Prostate cancer incidence and PSA testing patterns in relation to USPSTF screening recommendations. JAMA 2015;314:2054-61.

60. Stricker PD, Frydenberg M, Kneebone A, Chopra S. Informed prostate cancer risk-adjusted testing: a new paradigm. BJU Int 2012;110 Suppl 4:30-4.

61. Croswell JM, Kramer BS, Crawford ED. Screening for prostate cancer with PSA testing: current status and future directions. Oncology (Williston Park) 2011;25:452-60,463.

62. Royce TJ, Hendrix LH, Stokes WA, Allen IM, Chen RC. Cancer screening rates in individuals with different life expectancies. JAMA Intern Med 2014;174:1558-65. 